\title{
Gastroprotective mechanism of Paederia foetida Linn. (Rubiaceae) - a popular edible plant used by the tribal community of North-East India
}

\author{
Silpi Chanda ${ }^{1 *}$, Lokesh Deb², Raj Kumar Tiwari ${ }^{1}$, Kuldeep Singh ${ }^{1}$ and Sayeed Ahmad ${ }^{3}$
}

\begin{abstract}
Background: The objective of the present study is to evaluate the gastroprotective activity of Paederia foetida L. leaf for gastric ulcer.

Methods: The methanol extract of $P$. foetida $L$. leaves at two different dose levels was investigated for gastroprotective potential by using Indomethacin-pylorus ligation, alcohol induced and water immersion stress induced model in rats. In vitro $\mathrm{DPPH}^{*}$ radical scavenging activity and western blot analysis of stomach tissue from pylorus ligatures rats were also carried out. HPTLC analysis was done to understand the phyto-pharmacological relationship.

Results: Methanol extract at a dose level of $100 \mathrm{mg} / \mathrm{kg}$ and $200 \mathrm{mg} / \mathrm{kg}$ body weight showed 72 and $78 \%$ ulcer protection when compared to negative control whereas reference drug shown $82 \%$ protection in Indomethacin-pylorus ligation model. Further, methanol extract also showed protective effect against $70 \% \mathrm{v} / \mathrm{v}$ ethanol and stress induced gastric ulcer model. About $84 \%$ protection as compared to cimetidine (85\%) was seen in western blot analysis of stomach tissue from pylorus ligatures rats. HPTLC analysis of methanol extract of $P$. foetida $L$. confirmed the presence of $\beta$-sitosterol. In DPPH* radical scavenging activity, the $I_{50}$ value was observed to be $43.52 \mu \mathrm{g} / \mathrm{ml}$.

Conclusions: These observations established the traditional claim and thus Paederia foetida could be a potent gastroprotective agent for use in future. The gastroprotective activity might be mediated by the Nrf2 mediated antioxidant and anti secretory effects.
\end{abstract}

Keywords: Paederia foetida, Gastroprotective, Antioxidant, North-East India

\section{Background}

Paederia foetida Linn. belonging to the family Rubiaceae (Sanskrit, Prasarini) is an extensive foetid smelling climbing plant. The aerial parts of the plant contain iridoid glycosides viz. asperuloside, scandoside and paederoside [1]. Different tribal communities of North East to Southern part of India use the plant as a vegetable and also use to treat different stomach disorders like diarrhoea and dysentery [2-6], stomach swelling, to clean stomach, gastritis, in loose motion, indigestion,

\footnotetext{
*Correspondence: only_shilpi@yahoo.com

'Department of Pharmacy, Jaypee University of Information Technology

(JUIT), Wakhnaghat, Solan, Himachalpradesh 173234, India

Full list of author information is available at the end of the article
}

abdominal pain etc. [3,7-18]. The leaf is also used as an anti ulcer agent [19]. Various scientific study has been carried out to investigate the use of Paederia in the treatment of rheumatic affections [20-22], anti-inflammatory, hepatoprotective, [23-25], tripsyChemolithotripsy [26], promotes sexual vigour, increase the quantity of semen and body strength and to produce a youthful glow [27].

Peptic ulcer disease (PUD) is the most common gastrointestinal disorder in clinical practice. PUD results from an imbalance between defensive and corrosive factors, i.e. corrosive power of gastric hydrochloric acid and digestive power of pepsin as well as bile versus defensive factors, i.e. the ability of gastric and duodenal mucosa to resist these corrosive/digestive powers. 
Several side effects viz. hip fracture, acute interstitial nephritis, acute renal failure, osteoporosis, hepatitis, visual disturbance of currently available medicine for PUD has been reported [28-30]. Therefore, there is an urgent need to look for a better alternative treatment of PUD. Helicobacter pylori infection [31,32] and oxidative stress [33] are one of the major cause for the development of the PUD. Our previous studies on biological activity of Paederia against $H$. pylori and oxidative stress showed promising results [34,35]. In the light of these outcomes we further investigated the anti ulcer activity of the plant on animal models to evaluate the use of Paederia in the treatment of peptic ulcer. The present article describes our efforts and outcome.

\section{Methods}

\section{Ethnobotanical survey and Plant materials collection}

To know the importance, utility and therapeutic efficacy of the wild edible plants of Northeast, India, a survey [8] was conducted by the author S. Chanda. Agartala, capital of Tripura was chosen as a study area for the ethnobotanical survey. The survey was conducted randomly among the tribal families residing in and around Agartala. This ethno-pharmacological survey was carried out as per rules of Indian Biodiversity Act and Manipur Biological Diversity Rules, 2008 item No. 15(1) and 15(2), where stated that "citizen of India or corporate, association or organization registered in India under section 7 of the act are exempted from seeking prior/previous approval for the purposes of research, bio-survey and bio-utilization". The first main criteria to chose any consultants for the current study was the deep knowledge of the consultants in the use of plants and secondly the ability to speak and understand the different tribal and non tribal languages of Tripura. A general conversation also has been done with the several tribal medicine men (traditional practitioner) of that particular area. Here medicine man (locally known as Kaviraj/Baidya) is a healer who acquired deep knowledge on the use of plants as medicine from his or her forefather and use the knowledge to treat people when they are ill. For the current study the oral consent was obtained from the traditional practitioners. Total sample was considered by approaching direct interviews with individual tribal families and medicine men. A structured unbiased questionnaire format was prepared to facilitate the outcome of list of the plants used in the treatment of stomach disorders particularly ulcer. Medicine men were questioned about their diagnostic procedure, symptoms and the method of medication to treat stomach or duodenal ulcer. The most common symptoms described by the medicine men, which were further characterized as either ulceration in stomach or risk factors to developed ulceration are acidity, feeling of a full stomach, excessive abdominal pain which relieves after food consumption, loss of appetite with abdominal pain, belching with a sour taste etc. We have promised to respective traditional practitioners that the obtained traditional knowledge and sample will used only for our research purpose and will not disclosed their typical formulation or excipients to any one. After thorough analysis of the filled questionnaire format we identified that the plant Paederia foetida $\mathrm{L}$. is one of the most promising plant in the treatment of ulceration use by the tribal families. This plant is also very frequently advised by the medicine men to treat such disease as it is edible too. Fresh leaves of Paederia foetida Linn. (Rubiaceae) were collected from the local tribal market of Agartala, Tripura and authenticated by the National Institute of Science Communication and Information Resources, New Delhi (Authentication Ref No. NISCAIR/RHMD/Consult/201011/1442/40).

\section{Preparation of extract}

The leaf material was collected from Agartala, Tripura and extraneous matter were removed. The leaf material was dried in shade for 10 days and ground to get course powder (about $1.5 \mathrm{Kg}$ ). The ground material was extracted with methanol $(4.5 \mathrm{~L})$ in a Soxhlet apparatus for $24 \mathrm{~h}$. The temperature was maintained not exceeding $70{ }^{\circ} \mathrm{C}$ throughout the extraction procedure. The methanol extract was collected, filtered and evaporated to dryness on a rotary evaporator. The completely dried methanol extract was rewashed with distilled water, redried and stored in refrigerator until use. The yield of methanol free extract was $36.21 \% \mathrm{w} / \mathrm{w}$.

\section{Animals}

Healthy albino rats (Wistar strain) weighing 150 to $180 \mathrm{~g}$ were procured from Regional Institute of Medical Sciences (RIMS), Imphal. Ethical clearance for handling and experimentation on animals was obtained from the Institutional Animal Ethical Committee (IAEC), IBSD, Imphal with approval No.-IBSD/IAEC/Ext. Inst./PC/4 (1) prior to the beginning the experiment works. All studies were conducted in an accordance with the Animal Ethical Committee. The rats were acclimatized for one week under laboratory conditions to adopt in a new environment, where experiment was performed. They were housed in polypropylene cages and maintained at $25{ }^{\circ} \mathrm{C} \pm 2{ }^{\circ} \mathrm{C}$ temperature and $12 \mathrm{~h}$ dark/light cycle. They were fed with soya bean bori, Gram or standard pellet food once daily and water ad libitum throughout the experiments. The beding materials in the cages were renewed daily to ensure hygienic condition and maximum comfort for animals. 


\section{Determination of acute toxicity $\left(\mathrm{ALD}_{50}\right)$}

The acute toxicity for methanol extract of P. foetida was determined in albino mice, maintained under standard conditions. The animals were fasted overnight prior to the experiment. Acute oral toxicity - acute toxic class method (OCED Guideline no. 423, Annexure 2d) adopted by CPCSEA, Government of India was followed for toxicity studies. The mortality was observed after oral administration of $2000 \mathrm{mg} / \mathrm{kg}$ b.w test samples [36]. Common side effects such as, mild diarrhoea, loss of weight and depression of treated groups of animals was recorded within the 7 days of observation [37].

\section{Indomethacin-pylorus ligation-induced ulcer}

Albino rats were randomly divided into five groups, each consisted of 5 animals. The normal control (Group 1) and ulcer control (Group 2) groups received vehicle (distilled water; $5 \mathrm{ml} / \mathrm{kg}$, p.o.) throughout the course of the experiment. The treatment groups received different doses of methanol extracts of $P$. foetida (100 and $200 \mathrm{mg} / \mathrm{kg}$ b.w./day; Group 3 \& 4) and ranitidine (10 $\mathrm{mg} / \mathrm{kg}$, p.o./day; Group 5) for a period of four days. All the animals, other than those in the normal group, were administrated with indomethacin suspension $(25 \mathrm{mg} / \mathrm{kg}$, s.c.) once daily for four days as a ulcerogenic agent, 30 min after the administration of vehicle or test or standard drugs.

\section{Surgical procedure}

On the $4^{\text {th }}$ day $30 \mathrm{~min}$ after the treatment, surgical procedure was done [38]. The rats were fasted for $24 \mathrm{~h}$ before starting of surgical procedure. They were provided free access to water during this period. Each rat was anaesthetized with ether and the abdomen was opened through a midline incision. The pylorus located and ligated tightly with silk suture. Both the muscular layers and skin were then stitched with the help of suture and ligature separately. Four hours after pylorus-ligation, the animals were sacrificed by giving over dosage of ether. Stomach of all sacrificed rats was examined under microscope. The gastric damages in the glandular regions were located in the gastric mucosa as elongated black-red lines parallel to the long axis of stomachs.

\section{Calculation of ulcer index [39]}

Ulcer index $=(\mathrm{UN}+\mathrm{US}+\mathrm{UP}) \times 10^{-1}$; Where $\mathrm{UN}=$ Average of number of ulcer per animal

US $=$ Average of severity score, UP $=$ Percentage of animals with ulcers.

The percentage of ulcer protection was calculated by using the following formula:-
$\%$ of ulcer Protection

$$
=\frac{\text { Control mean ulcer index }- \text { test mean ulcer index }}{\text { Control mean ulcer index }} \times 100
$$

Determination of gastric volumes, $\mathrm{pH}$ and acid outputs

The stomachs of rats were excised out under ether anesthesia exactly after $4 \mathrm{~h}$ of pylorus ligation and the gastric contents were collected. The stomachs were washed with luke warm sterile water. Both the washing and gastric contents were collected and centrifuged together at 4000 RPM for $10 \mathrm{~min}$. The volumes of all the supernatants of gastric contents were measured and other gastric secretion studies, like $\mathrm{pH}$, acid output, acidity, ulcer index/ulcer score have also been done $[40,41]$. The $\mathrm{pH}$ of all supernatants was measured and their acidities were determined by titration to pH 7 with $0.1 \mathrm{~N} \mathrm{NaOH}$ solution.

The acid outputs were calculated by following equation:

Acid output $(\mu \mathrm{Eq} / \mathrm{hr})=\operatorname{Acidity}(\mathrm{mEq} / \mathrm{l}) \times$ Vol. of gastric juice $(\mathrm{ml}) / 4(\mathrm{hr})$

Acidity $=\frac{\text { Titre value of } \mathrm{NaOH} X \text { Actual normality of } \mathrm{NaOH}}{\text { Assumed normality of } \mathrm{NaOH}} \times 100$

\section{Alcohol induced gastric ulcer}

The animals were divided into five groups, each consisting of five rats. The ulceration was induced by administering $70 \%$ ethanol $(10 \mathrm{ml} / \mathrm{kg}$, p.o.). All animals were fasted for $36 \mathrm{~h}$ before administration of alcohol. Group 1 receiving distilled water $(5 \mathrm{ml} / \mathrm{kg}$, p.o.). Group 2 receiving $70 \%$ ethanol to induce gastric ulcer and $5 \mathrm{ml}$ distilled water $/ \mathrm{kg}$ p.o. as treatment, Group 3 \& 4 received methanol extracts of $P$. foetida (100 and $200 \mathrm{mg} / \mathrm{Kg}$, p.o.) one hour before administration of $70 \%$ ethanol as single dose. Sucralfate was administered to fifth group as reference standard drug at the dose $100 \mathrm{mg} / \mathrm{kg}$, p.o. one hour before administration of ethanol. They were kept in specially constructed cages to prevent coprophagia during and after the experiment. The animals were anaesthetized $4 \mathrm{~h}$ later with anesthetic ether and stomach was incised along the greater curvature and ulcer score was recorded [41]. The ulcer score for the normal stomach, red coloration, spot ulcer, hemorrhagic streak, ulcer and perforation is $0,0.5,1.0,1.5,2.0$ and 3.0 respectively.

\section{Water immersion stress induced ulcer (WISIU)}

The animals were divided into five groups, each group consisting of five rats. Group 1 (normal control) received distilled water $(5 \mathrm{ml} / \mathrm{kg}$, p.o.) where as group 2 treated as ulcer control. Group 3 and 4 received methanol extracts at the dose $100 \& 200 \mathrm{mg} / \mathrm{kg}$ b.w. respectively and group 5 received lansoprazole (8 $\mathrm{mg} / \mathrm{kg}$, p.o.). After treatment, animals were allowed to swim in a glass cylinder having water $\left(25^{\circ} \mathrm{C}\right)$ for $3 \mathrm{~h}$. Animals were killed by 
high dose of anesthetic ether and ulcer score was recorded [42].

\section{Western blot analysis of in-vivo stomach tissue from pylorus ligatures rats}

Animals were divided into four groups, each containing six and were starved for $24 \mathrm{~h}$ before experimentation. Group1 treated as normal control (+ control) and administrated water orally. The dose was $5 \mathrm{ml} / \mathrm{kg}$ b.w. Group 2 treated as an ulcer control (- control). Group 3 and 4 received $P$. foetida methanol extract $(150 \mathrm{mg} / \mathrm{kg}$ body weight, p.o.) and cimeditine ( $8 \mathrm{mg} / \mathrm{kg}$, body weight p.o.) respectively. After $30 \mathrm{~min}$ of treatment the pylorus located and ligated tightly with silk suture as described above in the indomethacin induced ulcer model. The stomachs of rats were removed and opened along the greater curvature and then washed with ice cold phosphate buffered solutions. The number of either erosions or ulcers was determined under the magnifying glass and gastric secretion studies have been done $[40,41]$.

Homogenates obtained from scratched gastric mucosa was centrifuged at $4000 \mathrm{RPM}, 4{ }^{\circ} \mathrm{C}$ for $30 \mathrm{~min}$ (5430R, Eppendorf). The supernatants containing 1:1000 protease inhibitor cocktail (P8340, Sigma-Aldrich) were kept into $-80^{\circ} \mathrm{C}$ until used. The proteins in tissue homogenates were separated by SDS-PAGE and transferred to polyvinylidene difluoride (PVDF) membranes (MerckMillipore), by means of trans blot turbo unit (BIO RAD). The transferred proteins were incubated with primary antibodies (Anti-Nr2f2; Ab1) produced in rabbit, washed and incubated with biotin conjugated secondary antibodies. After rewashing it was visualized by chromogenic method in SNAP-ID instrument (Merck- Millipore).

\section{Statistical analysis}

Data were expressed as mean \pm Standard Error Mean (SEM). Differences were considered significant at ${ }^{\text {**** }} P<0.001$, or ${ }^{* "} P<0.01$ or $" P<0.05$ when compared test group vs control (-ve) group and ${ }^{\alpha \alpha \alpha} P<0.001$, or ${ }^{\alpha \alpha} P<0.01$ or ${ }^{\alpha} P<0.05$ when compared positive control vs negative control. For numerical results, one-way analysis of variance (ANOVA) with Dunnett test (Positive control vs negative control and all test group vs. negative control) was performed using GraphPad InStat Version 3 (GraphPad Software).

\section{$\mathrm{DPPH}^{*}$ radical scavenging activity}

Though the antioxidant activity of the fresh leaves of Paederia also has been done by the author [34] but the same was also repeated with the dried sample (methanolic extract of dried leaf) used for the current animal study. The free radical-scavenging activity of methanol extract of Paederia was measured in terms of hydrogen donating or radical-scavenging ability using the stable radical DPPH. A solution of $0.1 \mathrm{mM} \alpha, \alpha$-diphenyl- $\beta$-picryl-hydrazyl (DPPH) (Himedia, Mumbai) in ethanol was prepared and $1.0 \mathrm{~mL}$ of this solution was added to $3.0 \mathrm{~mL}$ of the extract solution in water at different concentrations $(10-100 \mu \mathrm{g} / \mathrm{mL})$. Thirty minutes later, the absorbance was measured at $517 \mathrm{~nm}$ [43]. The lower absorbance of the reaction mixture indicates higher free radical-scavenging activity. Rutin (Ozone, Mumbai) was used as a standard drug. The results were expressed as $\mathrm{IC}_{50}$ or inhibitory concentration 50 value, i.e. concentration of samples exhibited $50 \%$ inhibition of DPPH* radicals.

\section{HPTLC analysis of methanol extract of $P$. foetida}

The methanol extract of $P$. foetida was evaluated by using high performance thin layer chromatography (HPTLC) system (Camag linomat 5, Switzerland) for qualitative estimation of $\beta$-sitosterol at $540 \mathrm{~nm}$. The commercially available $\beta$-sitosterol (Sigma-Aldrich; India) and methanol leaf extract of $P$. foetida was run simultaneously using mobile phase (toluene: ethyl acetate: formic acid in a ratio of 8:2:0.05 $\mathrm{v} / \mathrm{v} / \mathrm{v}$ ) and anisaldehyde sulphuric acid used as visualizing reagent.

\section{Results}

\section{Determination of acute toxicity (ALD50)}

In acute toxicity study, methanol extract of $P$. foetida does not show any mortality at the dose level of $2000 \mathrm{mg} / \mathrm{kg}$. Therefore $2000 \mathrm{mg} / \mathrm{kg}$ dose was considered as $\mathrm{ALD}_{50}$ cut off the dose under GHS 5 (safe dose), as per Globally Harmonised Classification System (GHS) for Chemical Substances and Mixtures described in OECD guideline 423 (Annexure 2b \& 3b). Common side effects such as, mild diarrhoea, loss of weight and depression in the treated group of animals were not observed within the 7 days of observation. In the present study, only $100 \mathrm{mg} / \mathrm{kg}$ (low) and $150 \mathrm{mg} / \mathrm{kg}$ (high) or $200 \mathrm{mg} / \mathrm{kg}$ (high) body weight doses were selected for in-vivo gastroprotective study and $10-100 \mu \mathrm{g} / \mathrm{mL}$ doses for ex-vivo and in-vitro studies. Because, $\geq 200 \mathrm{mg} / \mathrm{kg}$ body weight of extracts for in-vivo studies and $\geq 200 \mu \mathrm{g} / \mathrm{ml}$ of extract concentrations in invitro are likely to be artificial despite of yielding reproducible effects. Even worse, such high concentrations may trigger non-physiological effects resulting in artifacts [37].

\section{Indomethacin-pylorus ligation model}

In this model, administration of methanol extract of two different doses $(100$ and $200 \mathrm{mg} / \mathrm{kg}$ ) inhibited the increase in gastric secretion volume, acid output in a dose dependent manner whereas there is an increase in $\mathrm{pH}$. The effect was highly significant $(\mathrm{p}<0.001)$ for both the doses. The gastric ulcer index was decreased. It showed ulcer protection, 72 and $78 \%$ at the dose of 
Table 1 Effect of methanol extract on gastric secretion volume, pH, acid-output and ulcer index against indomethacin-pylorus ligation induced ulcer in rats

\begin{tabular}{|c|c|c|c|c|c|}
\hline \multirow[t]{2}{*}{ Treatment } & \multicolumn{3}{|c|}{ Gastric secretion (Mean \pm SEM) } & \multirow{2}{*}{$\begin{array}{l}\text { Ulcer index (mm) } \\
\text { Mean } \pm \text { SEM }\end{array}$} & \multirow{2}{*}{$\begin{array}{l}\% \text { of ulcer } \\
\text { protection }\end{array}$} \\
\hline & Volume (ml) & $\mathrm{pH}$ & Acid output (Eq/100 g/4 h) & & \\
\hline Group 1 (5 ml distilled water/kg) & $2.114 \pm 0.13$ & $2.80 \pm 0.01$ & $2.80 \pm 0.01$ & $2.850 \pm 0.07$ & - \\
\hline Group 2 Indomethacin (25 mg/kg) & $9.280 \pm 0.09^{\mathrm{aaa}}$ & $1.07 \pm 0.01^{\text {aaa }}$ & $24.47 \pm 2.28^{\text {aaa }}$ & $39.12 \pm 0.81^{\text {aaa }}$ & - \\
\hline Group3 MeOH PF (100 mg/kg) & $4.296 \pm 0.11^{* * *}$ & $2.51 \pm 0.02^{* * *}$ & $10.99 \pm 0.11^{* * *}$ & $10.57 \pm 0.15^{* * *}$ & 72.98 \\
\hline Group 4 MeOH PF (200 mg/kg) & $2.670 \pm 0.21^{* * *}$ & $2.71 \pm 0.71^{* * *}$ & $7.62 \pm 0.14^{* * *}$ & $8.38 \pm 0.05^{* * *}$ & 78.58 \\
\hline Group5 Ranitidine (10 mg/kg) & $2.426 \pm 0.52^{* * *}$ & $2.89 \pm 0.03^{* * *}$ & $5.30 \pm 0.31^{* * *}$ & $6.69 \pm 0.06^{* * *}$ & 82.89 \\
\hline
\end{tabular}

$\mathrm{MeOH}$ PF= methanol extract of Paederia foetida; $\mathrm{n}=5$; Data $=$ Mean \pm SEM; ${ }^{\text {aaa }} P<0.001$ (G1 Vs G2); ${ }^{* * *} P<0.001$, (Group 2 Vs Group 3, 4 \& 5)

100 and $200 \mathrm{mg} / \mathrm{kg}$, respectively, where ranitidine showed $82 \%$ of ulcer protection (Table 1 ).

\section{Alcohol induced gastric ulcer model}

Oral administration of ethanol induces ulcer. Pretreatment of such rats with different doses of the extracts showed highly significant protection to ulceration. 59 and $72 \%$ ulcer protection was seen in the dose of 100 and $200 \mathrm{mg} / \mathrm{kg}$, respectively, whereas standard drug sucralfate showed $81 \%$ of ulcer protection (Table 2).

\section{Water immersion stress induced ulcer (WISIU) model}

The methanol extract (100 and $200 \mathrm{mg} / \mathrm{kg}$ ) dose dependently showed highly significant $(\mathrm{p}<0.001)$ ulcer protection (62 and $67 \%$ ) to stomach mucosa of rats against WISIU where as lansoprazole showed $70 \%$ protection (Table 3).

\section{Western blot analysis of stomach tissue from pylorus ligatures rats}

As reported in Table 4 and Fig. 1 (F-1 to F-4), the effects of the methanol leaf extract of $P$. foetida at a dose of $150 \mathrm{mg} / \mathrm{kg}$, p.o. and cimetidine ( $8 \mathrm{mg} / \mathrm{kg}$, p.o.) prevented the development of acute gastric ulcer. Oral administration of the extract and cimetidine decreased ulcer index to $1.11 \pm 0.46$ and $1.00 \pm 0.23$ in comparison to ulcer control $7.00 \pm 0.63(\mathrm{p}<0.001)$, but acute gastric ulcer was developed significantly $(\mathrm{p}<0.001)$ in ulcer control when

Table 2 Effect of methanol extract of $P$. foetida on alcohol-induced gastric ulcer in rats

\begin{tabular}{|c|c|c|}
\hline Treatment & Ulcer score & $\begin{array}{l}\% \text { of ulcer } \\
\text { protection }\end{array}$ \\
\hline $\begin{array}{l}\text { Group } 1 \\
\text { (5 ml distilled water/kg, p.o.) }\end{array}$ & $2.0 \pm 0.12$ & - \\
\hline $\begin{array}{l}\text { Group } 2 \\
(5 \mathrm{ml} \text { distilled water }+70 \% \text { ethanol, } \\
10 \mathrm{ml} / \mathrm{kg} \text {, p.o.) }\end{array}$ & $3.70 \pm 0.49^{a}$ & - \\
\hline Group 3 MeOH PF (100 mg/kg) & $1.40 \pm 0.29^{*}$ & 59.45 \\
\hline Group 4 MeOH PF (200 mg/kg) & $1.0 \pm 0.31^{*}$ & 72.97 \\
\hline $\begin{array}{l}\text { Group } 5 \text { Sucralfate } \\
\text { (100 mg/kg, p.o.) }\end{array}$ & $0.70 \pm 0.12^{*}$ & 81.08 \\
\hline
\end{tabular}

$\mathrm{MeOH} \mathrm{PF}=$ methanolic extract of Paederia foetida; $\mathrm{n}=5$; Data $=$ Mean $\pm \mathrm{SEM}$;

${ }^{a} P<0.05$ (Group1 Vs Group2); ${ }^{*} P<0.05$, (Group 2 Vs Group 3, 4 \& 5) compared to the ulcer index of normal control animals $0.33 \pm 0.11$. Compared to the ulcer control rats, methanol extract of $P$. foetida and cimetidine pretreatment rats were shown a significant reduction in gastric volume, free acidity and total acidity $(\mathrm{P}<0.001)$. Figure 2 explained that in ulcer control (- control) group Nrf2 was not expressed, whereas in the normal control (+ control), methanol extract of $P$. foetida and cimetidine treated group showed expression of $\mathrm{Nrf} 2$.

\section{DPPH* radical scavenging activity}

In in-vitro assay, the $\mathrm{IC}_{50}$ values of reference standard rutin and methanol extract of $P$. foetida leaf was calculated $17.97 \mu \mathrm{g} / \mathrm{ml}$ and $43.52 \mu \mathrm{g} / \mathrm{ml}$ for $\mathrm{DPPH}^{*}$ radical scavenging effect respectively.

\section{HPTLC analysis of methanol extract of $P$. foetida}

HPTLC showed the presence of $\beta$-sitosterol like compound in methanol extract. The $R_{f}$ value of standard $\beta$-sitosterol compound was similar $\left(\mathrm{R}_{\mathrm{f}} \mathrm{0.38}\right)$ with one of the compounds visualized in the chromatogram of methanol extract at $540 \mathrm{~nm}$ and as well as after chemical treatment (Fig. 3).

\section{Discussion}

In our current study, we mainly focused the leaf portion of the plant on the basis of the outcome of the ethnobotanical field survey report conducted by the

Table 3 Effect of methanol extract of $P$. foetida on water immersion stress induced ulcer in rats

\begin{tabular}{lll}
\hline Treatment & Ulcer score & \% of ulcer protection \\
\hline $\begin{array}{l}\text { Group } 1 \\
\text { ( } \mathrm{ml} \text { distilled water/kg, p.o.) }\end{array}$ & $2.0 \pm 0.12$ & - \\
Group 2 (ulcer control) & $4.00 \pm 0.22$ & - \\
Group 3 (MeOH PF $100 \mathrm{mg} / \mathrm{kg}$, p.o.) & $1.50 \pm 0.27^{* * *}$ & 62.50 \\
Group 4 (MeOH PF $200 \mathrm{mg} / \mathrm{kg}$, p.o.) & $1.30 \pm 0.12^{* * *}$ & 67.50 \\
Group 5 & $1.20 \pm 0.26^{* * *}$ & 70.00 \\
(Lansoprozole $8 \mathrm{mg} / \mathrm{kg}$, p.o.) & & \\
\hline
\end{tabular}

$\mathrm{MeOH} \mathrm{PF}=$ methanolic extract of $P$. foetida; $\mathrm{n}=5$; Data $=$ Mean $\pm \mathrm{SEM}$;

${ }^{* * *} P<0.001$, (Group 2 Vs Group 3, 4 \& 5) 
Table 4 Effect of methanol extract of $P$. foetida on Pylorus-ligated rats

\begin{tabular}{|c|c|c|c|c|c|c|}
\hline Treatment & Mean ulcer Index (SEM) & $\%$ Protection & $\begin{array}{l}\text { Volume }(\mathrm{ml}) \text { of } \\
\text { gastric secretion }\end{array}$ & $\begin{array}{l}\text { Free Acidity } \\
\text { (Eq///100gm) }\end{array}$ & $\begin{array}{l}\text { Total Acidity } \\
(\mathrm{Eq} / / / 100 \mathrm{gm})\end{array}$ & $\mathrm{pH}$ \\
\hline $\begin{array}{l}\text { Group } 1 \text { Normal Control } \\
\text { (Distl. Water, } 5 \text { ml/kg, p.o.) }\end{array}$ & $0.33 \pm 0.11$ & - & $1.52 \pm 0.49$ & $71.97 \pm 1.04$ & $83.23 \pm 0.68$ & $3.65 \pm 0.11$ \\
\hline $\begin{array}{l}\text { Group } 2 \text { Ulcer Control } \\
\text { (Distl. Water, } 5 \mathrm{ml} / \mathrm{kg} \text {, p.o.) }\end{array}$ & $7.00 \pm 0.63^{* * * c}$ & - & $7.40 \pm 0.61^{* * * c}$ & $88.17 \pm 2.14^{* * * c}$ & $130.17 \pm 6.41^{* * * c}$ & $2.38 \pm 0.19^{* * * c}$ \\
\hline $\begin{array}{l}\text { Group } 3 \text { Methanol extract } \\
\text { (150 mg/kg, p.o.) }\end{array}$ & $1.11 \pm 0.46^{* * *}$ & 84 & $2.20 \pm 0.35^{* * *}$ & $50.17 \pm 5.12^{* * *}$ & $60.33 \pm 3.20^{* * *}$ & $5.42 \pm 5.50^{* * *}$ \\
\hline $\begin{array}{l}\text { Group } 4 \text { Cimetidine } \\
(8 \mathrm{mg} / \mathrm{kg}, \text { p. o.) }\end{array}$ & $1.00 \pm 0.23^{* * *}$ & 85 & $1.88 \pm 0.22 * * *$ & $36.00 \pm 5.29^{* * *}$ & $44.00 \pm 1.13^{* * *}$ & $7.42 \pm 0.15^{* * *}$ \\
\hline
\end{tabular}

Data were expressed as mean \pm Standard Error Mean (SEM), where $\mathrm{n}=6$ in each group. Differences were considered significant at ${ }^{* * *} P<0.001$ when compared control group vs ulcer control group (c) and Test groups vs ulcer control group. For numerical results, one-way analysis of variance (ANOVA) with Tukey-Kramer Multiple Comparison post tests were performed using GraphPad InStat Version 3 (GraphPad Software)

corresponding author [8] which revealed that leaf is only the part showing dual use as edible as well as medicine by the tribal people of Tripura. Secondly, extensive review of literature $(2004-2012)$ covered by the authors' concern to only the ethnobotanical survey report $(n=24)$ a total of $79.17 \%$ of articles claimed the use of leaf as ethnomedicine whereas $12.5 \%(n=3)$ claimed the use of whole plant, only $8.33 \%(n=2)$ stated the use of root and twig and $4.17 \%$ article claimed the use of stem, stem bark, aerial part and fruit individually. So in the present study, we focused to evaluate the Paederia leaf as gastroprotective agent on animal models. Our previous in vitro study [34, 35] also indicated the same. We tried to explore the mode of action which effect in physiological mechanism that caused ulcers. Though Reddy et al. [44] reported its anti ulcer activity of the aqueous and ethanol root extract of the plant, but there is still to go on protein based mechanism level. In the current study, western blot analysis of stomach tissue and antioxidant activity of the leaf extract explained the mechanism of gastroprotective activity. Ulcer protective activity might be mediated through Nrf2-antioxidant response element (ARE) pathway. Further, transcription factor Nrf2, a member of the Cap ' $n$ ' Collar family of bZIP proteins, is a central regulator in both constitutive and inducible AREcontrolled gene expression and innate immune response. Nrf2 mediated antioxidant response represents a critically important cellular defense mechanism that serves to maintain intracellular redox homeostasis and limit oxidative damage [45]. The Nrf2 expression was observed in the methanol extract of $P$. foetida and cimetidine treated groups, but not in ulcer control group. The above observations suggest the role of free radical scavenger(s) present in methanol extract of $P$. foetida induced gastro protective effect.

Uncontrolled acid secretion and ulceration of stomach mucosa due to several reasons have posed serious problems to the human health all over the globe [46]. There are several methods for the evaluation of gastric and duodenal antiulcer agents like pylorus ligation, stress ulcers, histamine, acetic acid, NSAIDs induced ulcers, reserpine induced solitary chronic gastric ulcers, serotonin-induced gastric mucosal lesions, cysteamine, dimaprit, endotoxin, dulcerozine, indomethacin plus histamine, MPTP (1methyl-4phenyl-1,2,3,6 tetrahydro pyridine) induced duodenal ulcers etc. Here we used those models which evaluate the basic mechanism of action involved, either $\mathrm{H}_{2}$ antagonism or anti-secretory or proton pump hydrogen potassium ATPase inhibitors (PPIs) or cytoprotection etc.

Indomethacin inhibits the activity of cyclo-oxygenase and decreases the formation of prostaglandins (PGs) [47-50], whereas it does not inhibit the lipoxygenase pathway of arachidonic acid. The increased level of LTs in gastric mucosa has potent action on the mucosal vasculature [51]. Lipid mediators play an important role in causing inflammation and pain. Indomethacin potentiates the
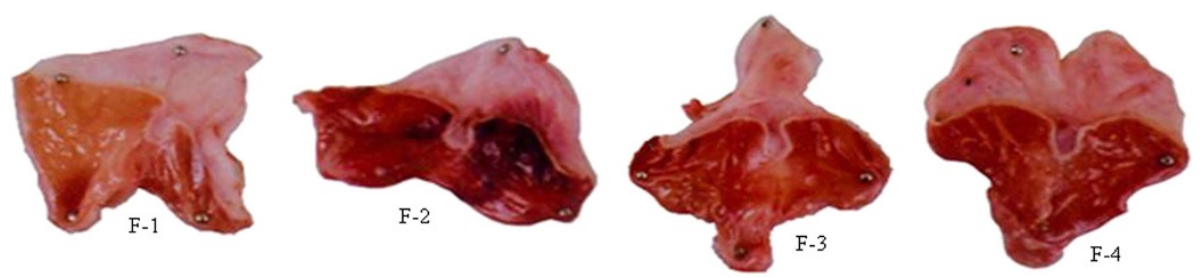

Fig. 1 Observation of ulcers in pylorus ligatures rats; F-1: Normal control group (+ Control), F-2: Ulcer control group (- Control), F-3: P. foetida treated group, F-4: Cimetidine treated group 
+ Control - Control P. foetida Cimetidine

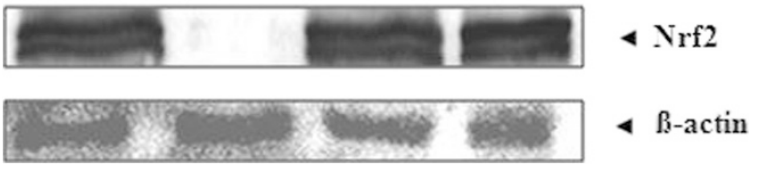

Fig. 2 Nrf2 expression in rat stomach demonstrated by western blot analysis of pylorous ligatured rat

secretary response elicited by histamine due to the inhibition of $\mathrm{PGE}_{2}$ synthesis. Therefore, induction of gastric ulcers and erosions is accompanied by progressive decrease in the level of $\mathrm{PGE}_{2}[52,53]$. In indomethacin-pylorus induced ulcer model methanol extract significantly decreased the gastric secretion volume, acid out-put and ulcer index while gastric $\mathrm{pH}$ was increased significantly in treated rats. This model indicates its anti secretary mechanism and revealed that the methanol extract of Paederia must contain active gastroprotective constituents as they effectively antagonized the gastric ulcerogenic effects.

Alcohol causes erosion and necrosis of superficial epithelial cells on gastric mucosa. Gastric damage in rats may be due to the production of leukotrienes and also involvement of 5-lipooxygenase. Prostaglandin also plays

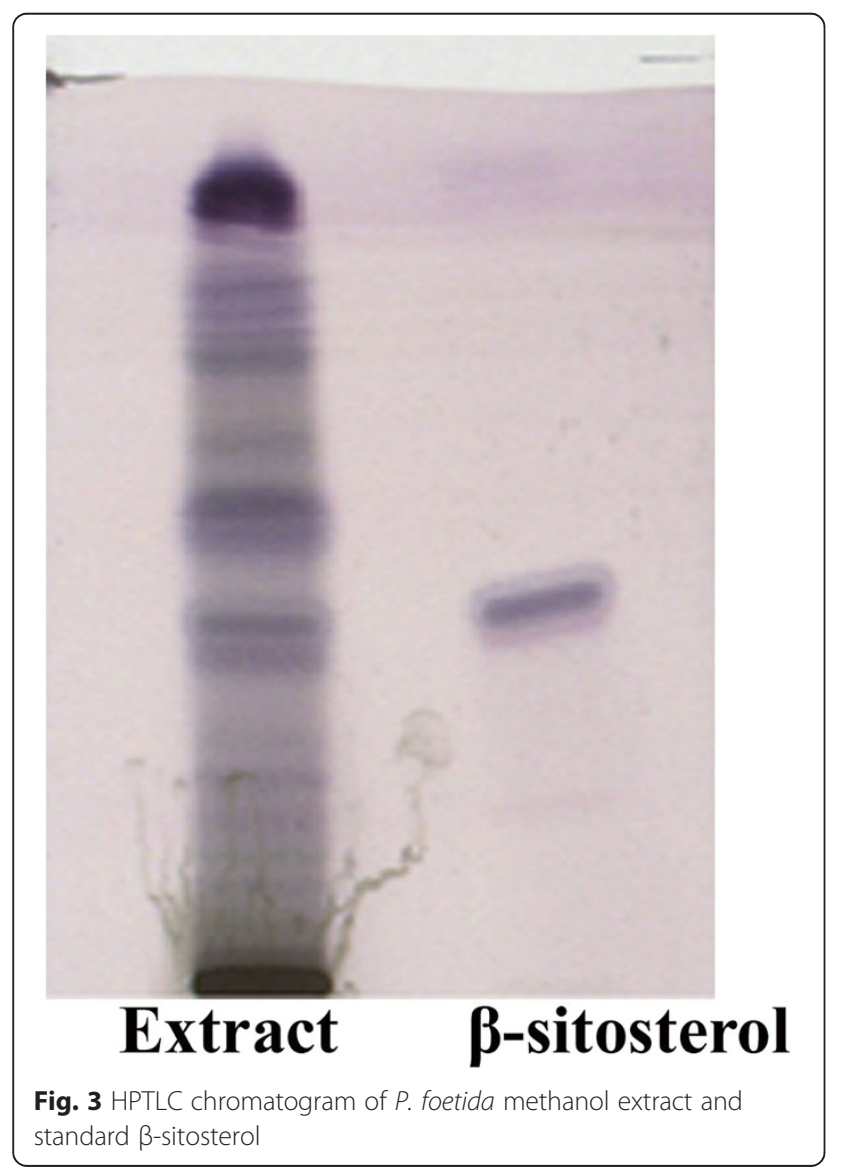

a role in alcohol induced ulcer [54, 55]. When compared with a positive control, decrease in mucosal resistance is considered to be the most important etiological reason in alcohol induced gastric ulcers. Even, there are reports that alcohol increases the secretion of protein into the gastric juice. In addition, alcohol develops ulceration by producing toxic oxygen derived free radicals [56]. Therefore, a cytoprotective agent that is capable of preventing the necrosis of mucus cell will be effective in this model, hence as a reference standard drug we chose sucralfate (a protective) not any anti secretory nor PPIs. On the other hand, in indomethacin model we chose ranitidine as a reference drug. In this model ulcer developed due to the more secretion of acid, so an antisecretory agent will be more effective rather than any protective agents.

The HPTLC analysis of the methanol leaf extract of Paederia reveals the presence of $\beta$-sitosterol in the extract that may play role in the ulcer protective mechanism. $\beta$-sitosterol was already reported for its antigastroulcerative activity [57] and anti-inflammatory properties thus it could be involved in anti ulcer property [58]. The presence of this bioactive also concrete the hypothesis of scavenging oxygen derived free radicals, generated due to alcohol, as literature supports its free radical scavenging activity also [59, 60].

Gastroprotective effect of $P$. foetida is further confirmed by WISIU model, in this case the lesion form due to both emotional and physiological stress. Lansoprazole is used to evaluate its proton pump inhibitor mechanism. The model showed almost similar ulcer protection (67\%) as standard drug lansoprazole (70 \%). Despite the introduction of highly effective $\mathrm{H}_{2}$ blockers and proton pump inhibitors, an effective anti-ulcer drug yet to discover, which will be not only act on one basic mechanism but also should have multiple mechanism of action to heal the peptic ulcer as well as effectively prevents their recurrence. The above observation suggested multiple mechanism and ulcer protective action of methanol leaf extract of $P$. foetida. This may be due to presence of multi-functional mixture of component in the extract. The study also justified the scientific use of $P$. foetida in traditional practice for the treatment of the stomach ache and we can outlook it for the development of new potential gastroprotective agents.

\section{Conclusion}

The present in vivo activity established the scientific basis of using of $P$. foetida in the treatment of peptic ulcer. The current investigation also concretes our previous in vitro outcomes. The ulcer protective activity of $P$. foetida might be mediated by the cholinergic action of Nrf2 mediated antioxidant and anti secretary effects. The antigastroulcerative activity, anti-inflammatory properties of $\beta$-sitosterol present in the methanol extract might also contribute a vital role in ulcer protective effects of $P$. foetida. However, 
efforts are on to investigate the role of main active principles present in the extract which are responsible for the ulcer protective activity.

\section{Competing interests}

The authors are declare that they have no competing interests.

\section{Authors' contributions}

Conceived and designed the experiments: LD, SC, KS, SA. Ethnobotanical survey and collection of the plant material: SC, RKT. Drying and extraction of plant material: SC, RKT. Conduct experiments: SC, RKT, LD. Concise review and analysis of manuscript: SC, LD, RKT, KS, SA. Analyses the statistical data and interpretation: SC, LD. Paper wrote: SC, LD, RKT. All authors read and approved the final manuscript

\section{Acknowledgements}

Acknowledging all the tribal community for allowing us to conduct the ethnobotanical survey, and Pharmacology Laboratory, IBSD, Department of Biotechnology, Government of India, Takyelpat Institutional Area, Imphal, Manipur, India for the animal activity.

\section{Author details}

'Department of Pharmacy, Jaypee University of Information Technology (JUIT), Wakhnaghat, Solan, Himachalpradesh 173234, India. ${ }^{2}$ Pharmacology Laboratory, Medicinal Plants and Horticultural Resources Division, Institute of Bioresources and Sustainable Development (Department of Biotechnology, Government of India), Takyelpat Institutional Area, Imphal 795001 Manipur, India. ${ }^{3}$ Department of Pharmacognosy and Phytochemistry, Jamia Hamdard, New Delhi 110062, India.

Received: 18 July 2014 Accepted: 26 August 2015 Published online: 03 September 2015

\section{References}

1. Shukla YN, Lloyd HA, Morton JF, Kapadia G. Iridoid glycosides and other constituents of Paederia foetida. Phytochemistry. 1976;15:1989-90.

2. Afroz S, Alamgir M, Khan MTH, Jabbar S, Nahar N, Choudhuri MSK. Antidiarrhoel activity of the ethanol extract of Paederia foetida Linn. (Rubiaceae). J Ethnopharmacol. 2006;105:125-30.

3. Barua U, Hore DK, Sarma R. Wild edible plants of ajuli island and Darrang districts of Assam. Indian J Tradit Know. 2007;6:191-4.

4. Borah PK, Gogoi P, Phukan AC, Mahanta J. Traditional medicine in the treatment of gastrointestinal diseases in upper Assam. Indian J Tradit Know. 2006;:5:510-2.

5. Basumatary SK, Ahmed M, Deka SP. Some medicinal plant leaves used by Boro (tribal) people of Goalpara district, Assam. Nat Prod Radiance. 2004;3:88-90.

6. Kar A, Borthakur SK. Medicinal plants used against dysentery, diarrhea and cholera by the tribes of erstwhile Kameng district of Arunachal Pradesh. Nat Prod Radiance. 2008;7:176-81.

7. Kalita D, Phukan B. Some Ethnomedicine used by the Tai Ahom of Dibrugarh district, Assam, India. Indian J Nat Prod Resour. 2010;1:507-11.

8. Chanda S, De B, Tiwari RK. Traditional and ethnobotanical investigation of some edible plants among the tribes of Tripura, India. In: Choudhury MD, Sharma GD, Choudhury S, Talukdar AD, editors. Status and conservation of bio-diversity in North East India. Delhi: Swastik publications; 2011. p. 118-24.

9. Das P. Wild tribal plants of Tripura tribes. Agartala: Tripura Tribal Cultural Research Institute \& Museum, Govt of Tripura; 1997.

10. Kagyung R, Gajurel PR, Rethy P, Singh B. Ethnomedicinal plants used for gastrointestinal disease by Adi tribes of Dehang-Debang Biosphere Reserve in Arunachal Pradesh. Nat Prod Radiance. 2010;9:596-601.

11. Kala CP. Ethnomedicinal botany of the Apatani in the Eastern Himalayan region of India. J Ethnobiol Ethnomed. 2005;1:11.

12. Kar A, Borthakur SK. Wild vegetables of Karbi-Anglong district Assam. Nat Prod Radiance. 2008;7:448-60.

13. Pfoze NL, Kumar Y, Myrboh B. Survey and assessment of ethnomedicinal plants used in Senapati district of Manipur State, Northeast India. Phytopharmacology. 2012;2:285-311.

14. Reddy KN, Pattanaik C, Reddy CS, Raju VS. Traditional knowledge on wild food plants in Andhra Pradesh. Nat Prod Radiance. 2007;6:223-9.
15. Sarmah TR, Adhikari D, Majumdar M, Arunachalan A. Traditional medicobotany of Chakma community residing in the Northwestern periphery of Namdapha National park in Arunachal Pradesh. Nat Prod Radiance. 2008;7:587-93.

16. Srivastava C, Singh RK, Apatani Community, Mukherjee TK. Indigenous biodiversity of Apatani plateau: learning on biocultural knowledge of Apatani tribe of Arunachal Pradesh for sustainable live hoods. Nat Prod Radiance. 2010;9:432-42.

17. Sumpam T, Nima DN, Chocha A, Litin A. An ethnobotanical survey of medicinal plants in the Eastern Himalayan zone of Arunachal Pradesh, India. J Ethnopharmacol. 2011;134:18-25.

18. Rethy P, Singh B, Kagyung R, Gajurel P. Ethnobotanical studies of Dehang-Debang Biosphere Reserve of Arunachal Pradesh with special reference to Memba tribes. Nat Prod Radiance. 2010;9:61-7.

19. Chanda S, Sarethy IP, De B, Singh K. Paederia foetida- a promishing ethnomedicinal tribal plant of Northeast India. J Forestry Res. 2013;24:801-8.

20. Chhetri DR, Parajuli P, Subba GC. Antidiabetic plants used by Sikkim and Darjeeling Himalayan tribes, India. J Ethnopharmacol. 2005;99:199-202.

21. Rajashekhara N, Sharma PP, P Vasanth: Comparative study of Prasarni [Merremia tridentate Hallier.f. (Convulvulaceae) and Paederia foetida (Rubiaceae)] in Amavata(Rheumatoid arthritis). Ayu 2009;30:503-507

22. Hynniewta SR, Kumar Y. Herbal remedies among the Khasi traditional healers and village folks in Meghalaya. Indian J Tradit Know. 2008;7:581-6.

23. Srivastava MC, Tewari JP, Kant V. Anti-inflammatory activity of Paederia foetida (Gandhali). Indian J Med Sci. 1973;27:231-4.

24. De S, Ravishankar B, Bhavsar GC. Evaluation of Paederia foetida for hepatoprotective and anti-inflammatory activities. Indian J Nat Prod. 1993;9:7-11.

25. De S, Ravishankar B, Bhavsar GC. Investigation of the anti-inflammatory effects of Paederia foetida. J Ethnopharmacol. 1994;43:31-8.

26. The Wealth of India. A dictionary of Indian raw materials and industrial product, raw materials, vol 7. New Delhi: Council for Scientific and Industrial Research (CSIR); 2001.

27. Raghunathan K, Mitra R. Pharmacognosy of indigenous drugs vol 2. Central Council for Research in Ayurveda and Siddha: New Delhi; 1982.

28. Geevasinga N, Coleman PL, Webster AC, Roger SD. Proton pump inhibitors and acute interstitial nephritis. Clin Gastroenterol Hepatol. 2006:4:597-604.

29. Viana De Miguel C, Alvarez GM, Sanchez SA, Carvajal GPA. Lansoprazole-induced hepatitis. Medicina Clinica (Barcelona). 1997;108:599.

30. Yang YX, Lewis JD, Epstein S, Metz DC. Long-term proton pump inhibitor therapy and risk of hip fracture. JAMA. 2006;296:2947-53.

31. NIH Consensus Development Panel on Helicobacter pylori in Peptic Ulcer Disease. Helicobacter pylori in peptic ulcer disease. JAMA. 1994;272:65-9.

32. Correa P. Human gastric carcinogenesis, a multistep and multifactoria process- first American Cancer Society Award lecture on cancer epidemiology and prevention. Cancer Res. 1992;52:6735-40.

33. Tandon R, Khanna HD, Dorababu M, Goel RK. Oxidative stress and antioxidants status in peptic ulcer and gastric carcinoma. Indian J Physiol Pharmacol. 2004:48:115-8.

34. Chanda S, Ahmed S, Singh K. Comparison of in vitro antioxidant potential of fractionated Paederia foetida leaf extract. Int J Drug Dev Res. 2014;6:280-5.

35. Chanda S, Gehlot V, Das R, Mahant S, Das K, Singh K, et al. Antimicrobial activity of Paederia foetida against drug resistant $H$. pylori isolates from India. World J Pharm Res. 2014;3:1234-43.

36. Veerarghavan, P. Expert consultant, Committee for the Purpose of control and supervision of Experiments on Animals (CPCSEA). Animal Welfare Division, Government of India (Guideline No. 423, Annexure-2d of OECD). 19th September, 2001.

37. Deb L, Dutta A. Evaluation of mechanism for antihypertensive action of Clerodendrum colebrookianum Walp., used by folklore healers in North-East India. J Ethnopharmacol. 2012;143:207-12.

38. Goel RK, Chakrabarti A, Sanyal AK. The effect of biological variables on the anti ulcerogenic effect of vegetable plantain banana. Planta Med. 1985;2:85-8.

39. Vogel GH. Drug discovery and evaluation. New York: Springer Verlag Berlin Heidelberg; 2002.

40. Shay H, Komarov SA, Fele SS, Meranze D, Gruenstein H, Siplet HA. Simple method for uniform production of gastric ulceration in rat. Gastroenterology. 1945;5:43-61.

41. Kulkarni SK. Hand book of experimental pharmacology. Vallabh Prakashan: New Delhi; 1999 
42. Brzozowski T, Konturek SJ, Kwiecien S, Pajdo R, Brzozowski I, Hahn EG. Involvement of endogenous cholecystokinin and somatostatin in gastro protection induced by intra duodenal fat. J Clin Gastroenterol. 1998;27:125-37.

43. Alder R. In Breakdown in Human Adaptation to Stress. Boston: Martinus Ninjihoff; 1984.

44. Reddy KS, Kumar AS, Ganapaty S. Evaluation of anti ulcer activity of Paederia foetida root extracts in experimentally induced gastric ulcer in rats. Int J Res Ayurveda Pharm. 2011;2:1556-9.

45. Pi J, Zhang Q, Woods CG, Wong V, Collins S, Andersen ME. Activation of Nrf2 - mediated oxidative stress response in macrophages by hypochlorous acid. Toxicol Appl Pharmacol. 2008;226:236-43.

46. Bandyopadhyay D, Biswas K, Bandyopadhyay U, Reiter RJ, Banerjee RK. Melatonin protects against stress-induced gastric lesions by scavenging the hydroxyl radical. J Pineal Res. 2000;29:143-51.

47. Smith WL, Marnett LJ. Prostaglandin endoperoxide synthase : structure and catalysis. Bochim Biophys Acta. 1991;1083:1-17.

48. Smith WL, Garavito RM, Dewill DL. Prostaglandin endoperoxide H synthases (Cyclooxygenase)-1 and -2. J Biol Chem. 1996;271:33157-60.

49. Herschman HR. Prostaglandin synthase 2. Biochim Biophys Acta. 1996;1299:125-40.

50. Needleman P, Isakason PC. The discovery and function of COX-2. J Rheumatol Suppl. 1997;24:6-8.

51. Kapui Z, Boer K, Rozsa I, Blasko GY, Hermeez I. Investigation of indomethacin induced ulcer in rats. Arzneimittelforschung. 1993;43:767-71.

52. Reeves JJ, Stables R. Effects of indomethacin, piroxicam and selected prostanoids on gastric acid secretion by the rat isolated gastric mucosa. Br J Pharmacol. 1985;86:677-84.

53. Christopher JS, Yan Z, Carol M, Koboldt JM, Ben SZ, John JT, et al. Pharmacological analysis of cyclooxygenase-1 in inflammation. Proc Natl Acad Sci. 1998;95:13313-8.

54. Aktay G, Tozkoparan B, Ertan M. Effects of nonsteroidal anti-inflammatory drugs on the thiol groups and lipid peroxidation in ethanol induced oxidative stress. Acta Pharm. 2004:46:107-12

55. Bandyopadhyay U, Das D, Bandyopadhyay D, Bhattacharjee M, Banerjee RK. Role of reactive oxygen species in mercapto-methylimidazole induced gastric acid secretion and stress induced gastric ulceration. Curr Sci. 1999;76:55-63.

56. Deb L, Dubey SK, Jain A, Jain AK, Pandian GS. Preventive effect of Thuja occidentalis on gastric ulcer - a novel role of free radical scavenger. J Nat Remedies. 2009;9:152-8.

57. Xiao M, Yang Z, Jiu M, You J, Xiao R. The antigastroulcerative activity of beta-sitosterol-beta-D-glucoside and its aglycone in rats. Hua Xi Yi Ke Da Xue Xue Bao. 1992;23:98-101.

58. Onasanwo SA, Elegbe RA. Antinociceptive and anti-inflammatory properties of the leaf extracts of Hedranthera barteri in rats and mice. African J Biomed Res. 2006;9:109-17.

59. Van Rensburg SJ, Daniels WM, van Zyl JM, Taljaard JJ. A comparative study of the effects of cholesterol, beta-sitosterol, beta-sitosterol glucoside, dehydroepiandrosterone sulphate and melatonin on in vitro lipid peroxidation. Metab Brain Dis. 2000;15:257-65.

60. Ruijie HE, Biqun Z, Hong F, Ye Z, Yingrui W. Free radical scavenging activities of sitosterol extracted from Abies yuan banensis. Asian J Chem. 2013;25:3507-8.

\section{Submit your next manuscript to BioMed Central and take full advantage of:}

- Convenient online submission

- Thorough peer review

- No space constraints or color figure charges

- Immediate publication on acceptance

- Inclusion in PubMed, CAS, Scopus and Google Scholar

- Research which is freely available for redistribution 